Kamila Rezmer

Nicolaus Copernicus University (Poland)

\title{
IV Winter Methodological School - A Report
}

Winter Methodological School is annual event organized jointly by the Polish Political Science Association and the Department of Political Theory at the Faculty of Political Science and International Studies (FoPSaIS), Nicolaus Copernicus University (NCU). The fourth edition of the conference took place February 21-22, 2019, at the FoPSaIS, NCU in Thorn, Poland. It was a great opportunity for scholars in political science to improve their scientific workshop through presenting their research projects to the conference audience and invited experts reviewing the projects.

The first day of the conference was opened with the lecture of Aneta Pazik, PhD, who was representing National Research Centre in Poland. Dr Pazik presented NRC's grants that both young and more experienced scholars can apply for. She also gave the participants hints how to prepare a grant submission properly, i.e. how to avoid basic and the most common mistakes.

The first working panel began after the lecture. The first presenting participant was Rafał Kamprowski, PhD, who in his presentation entitled "Bezpieczeństwo zdrowotne seniorów w europejskiej sieci zdrowych miast" took as an aim the identification of the types of older people standpoints towards security assured by cities. Then, prof. Monika Klimowicz and prof. Małgorzata Michalewska-Pawlak presented a project "Implementacja inwestycji społecznych w państwach członkowskich Unii Europejskiej”. The authors explained that their research concentrates on implemented models and social investments in such areas as family, education and labor policy in 1990-2020 in eight EU countries. Another presenting person was Wojciech Łysek, $\mathrm{PhD}$, who told about his interest in Juliusz Mieroszewski and a research project "Aktualność rozważań Juliusza Mieroszewskiego w zakresie polskiej polityki wschodniej po 2015 roku" that aims to create an intellectual biography of Mieroszewski. Dr Łysek justified his goal by claiming that Mieroszewski’s thought still impacts Polish foreign policy which is discernible especially in the context of relations with the East. 
Second panel was opened by Marta Cimke with a project entitled "Wpływ dewolucji na partie polityczne i system partyjny w Zjednoczonym Królestwie Wielkiej Brytanii i Irlandii Północnej". An assumption underlying the idea was that there is a research gap within the area designated by devolution and its influence on the functioning of political parties in the United Kingdom and Norther Ireland. The author claimed she will study that relation in three fields: parties' structure, their electoral strategies and polity. Next participant was Karol Piękoś, MA, with a project "Istota instytucji nadzoru nad działalnością samorządu terytorialnego" in which he tried to present from the perspective of political science how does a supervising institution function. A person closing the panel was Grzegorz Mazur, MA, who presented the topic "Jak pracuje umysł wybitnego polityka - Jarosław Kaczyński - studium przypadku”. The researcher wanted to focus on the analysis of Kaczyński's life, his speeches, etc. to establish what and in what degree influenced the worldview of the politician.

After a lunch break Damian Wicherek, MA, presented a project "Kancelaria Prezydenta Rzeczypospolitej jako organ pomocniczy". He wanted to point out differences in the functioning of all presidential cabinets from the times of Lech Wałęsa to the present moment - the cabinet of Andrzej Duda; also, the author wanted to outline how a presidential cabinet facilitates the realization of the constitutional rights of a Polish president. A second person in the panel and the last participant of that day was Ewelina Nowakowska, MA, who spoke on political identity in the presentation "W jaki sposób mówić o autoidentyfikacji ideowej młodej prawicy i młodej lewicy w Polsce po 2015 roku? Refleksja nad tożsamością polityczną”. The young researcher undertook a very complicated, interdisciplinary task - to investigate worldviews of publicly recognized people in Poland. After discussing the methodology, she also presented her initial results.

The first day of the conference was ended with a lecture given by prof. Roman Bäcker and Joanna Rak, $\mathrm{PhD}$, on the structure of scientific paper. The experts discussed various configurations of an article and a typical reviewing policy in the best scientific journals in the world. There was an official reception after the lecture.

Because of a big interest in the event, the second day was divided in two simultaneous panels. The first panel was opened by Bartosz Płotka, MA, - secretary of the conference - who presented the topic "The Dynamics of Biopolitical Thought in Poland. A Fuzzy Set Analysis of Polish Biopolitical Bills in 1989-2015". The author told about his innovative approach to studying political (biopolitical in this case) thought by using Qualitative Comparative Analysis (QCA). Then there was the presentation of Bartosz Mazurkiewicz, MA, titled "Polityczne i pozapolityczne czynniki wielokadencyjności burmistrzów - w poszukiwaniu prawidłowości". The author proposed political factors such as competitiveness, position of mayor's electoral committee or intensification of electoral competitiveness for studying terms of offices of mayors. Non-political factors were divided by him in two groups: the first comprised individual incomes and expenditures, while the second included unemployment and poverty. 
The second panel was started by the presentation "Kreowanie wizerunku gminy na przykładzie miast na prawach powiatu województwa podkarpackiego" given by Dominik Boratyn. The participant approached his speech interactively and asked some questions to the audience. Then he explained the answers and demonstrated how can this mechanism work in his project. Next presentation was made by Maria Lewandowska, MA. It was titled "Relacje ukraińsko-rosyjskie według tweedów Petra Poroszenki i Dmitrija Miedwiediewa". The author proposed the contemporary look at the international relations through the glass of social media, Twitter in this case. Another project was presented by Tomasz Sińczak, MA, who intended to study Russia's engagement into the conflict in Syria, assuming that these activities did not help Russia to come back to the Concert of Europe. His topic was titled "Wojna domowa w Syrii. Powrót Rosji do koncertu mocarstw?". The last speech was given by the author of this report, i.e. Kamila Rezmer, MA. The project was entitled "Agenda kościelna a polityczna w Polsce w latach 2015-2019”. The proposal concerned investigating relations between Catholic Church in Poland and politics with the methodology proper to agendasetting studies which focus on studying the transfer of issue salience between outlined agendas. The second day of the conference was ended with the lecture "How to Construct a Theory?" given by prof. Kazimierz Dziubka. The professor demonstrated the intricacies, traps and potential waiting in political theory studies as well as its current directions.

The Winter Methodological School is undoubtedly a big success and one of few conferences at which scholars may present rather their research projects than fully-fledged studies, which are reviewed by the most prominent experts. This year experts were prof. Kazimierz Dziubka (Wrocław University), prof. Roman Bäcker (NCU), Aneta Pazik, PhD (NRC), Joanna Rak, PhD (AMU), Krzysztof Kasianiuk, PhD (Collegium Civitas), and Wiktor Szewczak, PhD (NCU). The consultations were held in very friendly atmosphere and certainly will positively impact the presented research projects.

\section{Author}

\section{Kamila Rezmer}

Nicolaous Copernicus University in Toruń, Poland, e-mail: krezmer@doktorant.umk.pl 